\title{
Characterization of the medium-density fiberboard obtained through acid digestion to produce bio-oil and carbon black
}

Caracterização de fibra de média densidade obtidos de digestão ácida para produção de bioóleo e negro de fumo

Matheus Severo Schalenberger ${ }^{1}$, Evandro Stoffels Mallmann², Hélcio José Izário Filho ${ }^{3}$, Joana Bratz Lourenço $^{1}$, Ritielli Berticelli ${ }^{4}$, Germano Possani ${ }^{1}$, Rodrigo Fernando dos Santos Salazar ${ }^{1}$

1,4,6,7 Franciscan University - Santa Maria - RS, Brazil

matheus_severo7@hotmail.com; joanab_lourenco@hotmail.com; germano.possani@unifra.br; r.f.s.salazar@gmail.com

${ }^{2}$ Federal University of Santa Maria

engqui.butia@gmail.com

${ }^{3}$ University of São Paulo - USP

helcio@dequi.eel.usp.br

${ }^{4}$ Cruz Alta University

rberticelli@unicruz.edu.br

\begin{abstract}
Solid wastes from furniture industries require proper disposal and may have potential to be used as input in other production chains. The aim of the current study is to assess the use of medium density fiberboard (MDF) to produce bio-oil and carbon black with low emission of toxic elements. A full factorial design was used to assess 27 bio-oil preparation procedures based on the acid digestion of MDF shavings. The influence of three concentrated acid types $\left(\mathrm{HNO}_{3}, \mathrm{H}_{2} \mathrm{SO}_{4}\right.$ and $\left.\mathrm{HCl}\right)$ at three different temperatures $\left(25,75\right.$ and $\left.150^{\circ} \mathrm{C}\right)$ and digestion times $(30,60$ and $90 \mathrm{~min})$ was assessed. The contents of $\mathrm{Al}, \mathrm{Ba}, \mathrm{Cd}, \mathrm{Cr}, \mathrm{Cu}, \mathrm{Ni}$ and $\mathrm{Pb}$ samples were determined through ICP OES. The Al and Ba contents oscillated between 442.2 $\pm 235.9 \mathrm{mg} \mathrm{kg}^{-1}$ and $17.9 \pm 8.6 \mathrm{mg} \mathrm{kg}^{-1}$, respectively. The $\mathrm{Cd}, \mathrm{Cr}$, Ni and Pb contents were below the detection limit set by the technique. The tests showed that the studied material has the potential to be used as bio-oil and carbon black with low emission of metallic elements; thus, it was considered a potential alternative source of biomass-generated energy and, in parallel, it provides the furniture sector with an additional waste management option.
\end{abstract}

Keywords: Biomass. MDF. Solid Waste.

\section{Resumo}

Os resíduos sólidos oriundos das indústrias moveleiras demandam correta destinação e podem apresentar potencial para ser empregado como insumo em outras cadeias produtivas. O presente estudo tem por objetivo avaliar o emprego do resíduo de Fibra de Média Densidade (MDF), para produção de bio-óleo e negro de fumo com baixa emissão de elementos tóxicos. Empregou-se um planejamento fatorial completo para avaliar 27 procedimentos de preparo do bio-óleo através da digestão ácida da maravalha de MDF. Foram avaliados a influência de três tipos de ácidos concentrados $\left(\mathrm{HNO}_{3}, \mathrm{H}_{2} \mathrm{SO}_{4}, \mathrm{HCl}\right)$, em três temperaturas distintas $\left(25,75\right.$ e $\left.150^{\circ} \mathrm{C}\right)$, em três tempos de digestão $(30,60$ e 90 min). Determinou-se os teores de $\mathrm{Al}, \mathrm{Ba}, \mathrm{Cd}, \mathrm{Cr}, \mathrm{Cu}$, Ni e Pb das amostras por ICP-OES. Os teores de Al e Ba oscilaram em 442,2 $\pm 235,9 \mathrm{mg} \mathrm{kg}^{-1}$ e $17,9 \pm 8,6 \mathrm{mg} \mathrm{kg} \mathrm{kg}^{-1}$ respectivamente. Os teores de $\mathrm{Cd}$, $\mathrm{Cr}$, Ni e Pb ficaram abaixo do limite de deteç̧ão da técnica. A partir dos ensaios verificou-se que o material estudado apresentou potencial para ser empregado como bio-óleo e negro de fumo, sendo considerado uma potencial fonte alternativa de energia por biomassa e, paralelamente, permitir ao setor moveleiro mais uma possibilidade de gestão dos resíduos.

Palavras-chave: Biomassa. MDF. Resíduos Sólidos. 


\section{Introduction}

The concern with environmental pollution issue has considerably increased, mainly due to the so-called “ecological crisis". Society's capacity to harm the environment has increased due to population growth and to constant technological development. On the other hand, there is the hope and belief that science and technology can make relevant contributions to a sustainable development (MOHAN et. al, 2006; MOTA, 2014; BERWANGER et al., 2015; PATEL; KUMAR, 2016; DHANAVATH et al., 2017).

The search for alternative chemical products and energy generation means grows every year due to concern with the possible depletion of fossil reserves, as well as to environmental concerns (TORRI, 2013). Renewable energy sources such as biomass play a key role in the energy, environmental and socio-economic scenario (DHANAVATH et al., 2017). Furthermore, the waste produced by furniture industries is often discarded in the environment or used as fuel in boilers and the like. Accordingly, 10 to $15 \%$ of the reconstituted wood panels become waste in the form of wood shavings or cutouts. The so-called particle board and medium density fiber (MDF), which are largely generated in this type of enterprise, stand out among the main residue groups (ABREU et al., 2009; FERREIRA, 2013; DHANAVATH et al., 2017).

According to Vaz Júnior (2011), chemical products made out of co-products and residues have the greatest potential to add value to biomass production chains due to the strategic participation of the chemical industry in the input and product supply to several economy sectors such as the petrochemical, pharmaceutical and the construction sectors, among others (VAZ JÚNIOR, 2011; BERWANGER et al., 2015; DHANAVATH et al., 2017).

Thus, the present study is justified by the concern with developing and implementing methods able to assure sustainability in one of the stages comprising the furniture production chain (MOHAN et. al, 2006). Moreover, the present research assesses a procedure for the treatment of industrial solid MDF wastes and, concurrently, seeks to add value by converting waste into constituents of industrial interest. The aim of the current study was to assess the acid digestion process used in the degradation of synthetic resins, paraffin and additives found in MDF waste in order to produce biooil and carbon black.

\section{Theoretical background}

The current section presents some important subjects concerning the study, as well as the main concepts and points for the development of the herein presented research.

\section{Biomass}

The use of biomass as the main global energy source diminished as fossil fuels emerged. Nowadays, this scenario is changing, since biomass is one of the energy-production sources showing the greatest growth potential every year (TORRI, 2013; ZHANG et al., 2013; PATEL; KUMAR, 2016).

Biomass is defined as any material essentially composed of carbon, hydrogen and oxygen able to be converted into energy (KLASS, 1988; HUBER et al., 2006). Biomass can be found in woody and non-woody plants, such as timber and its wastes, as well as in organic wastes such as agricultural, urban and industrial residues. In addition, biomass is also found in biofluids such as vegetable oils (e.g., castor beans and soybean) (CORTEZ et al., 2008; PATEL; KUMAR, 2016; KAN et al., 2016). 
The international and the domestic markets often see biomass as one of the main alternatives to diversify the energy matrix and, consequently, to reduce the world's dependence on fossil fuels. Biomass can be defined as any renewable resource derived from organic matter of animal, vegetable or micro-organism origin able to be converted into energy (TORRI, 2013; KAN et al., 2016).

Forest wastes play a key role in biomass availability in some countries, since they are generated in substantial amounts during harvesting and industrial procedures. This energy source has found a place in the market due to the technological development, as well as to the low costs representing its efficient use (CORTEZ et al., 2008; KAN et al., 2016). There are different biomass-use alternatives such as woodchip waste reuse to make small objects and adornments, as well as chemical or physical treatments applied to generate new inputs, such as carbon black, furfural and hydroxymethylfurfural, to be applied in the energy sector or even in the chemical production chain (ABREU et al., 2009). It is obvious that the use of biomass plays a key role in the obtainment of renewable chemical inputs; thus, it is necessary setting chemical routes and methods able to make its reuse feasible. In addition, the resulting diversification of products will certainly have positive impacts on the chemical industry and on the energy sector, fact that may generate great benefits to society (VAZ JÚNIOR, 2011; KOUCHAKI-PENCHAH et al., 2016).

\section{Medium Density Fiberboard (MDF) Wastes}

Medium Density Fiberboard (MDF) is a reconstituted wood panel composed of wood fibers subjected to agglutination and compaction processes based on the joint action of pressure and heat inside presses. The wood fibers undergo a synthetic resin application process to fixate the material (JUVENAL; MATTOS, 2002; KOUCHAKI-PENCHAH et al., 2016).

The MDF is consistent and presents some mechanical features that approximate it to solid wood. It also presents physical resistance parameters superior to those of agglomerated wood-based panels, as well as good dimensional stability and excellent machining capacity. The panels are made of planted-forest wood belonging to genera Pinus and Eucalyptus (JUVENAL MATTOS, 2002; KOUCHAKI-PENCHAH et al., 2016). According to Maffessoni and Meneguzzi (2012), the furniture industries consume massive MDF amounts; $17.12 \%$ of this total corresponds to waste generated during the production processes. This MDF waste may be found in the form of wood powder, sawdust, wood shavings and woodchips (MAFFESSONI; MENEGUZZI, 2012; PIEKARSKI et al., 2017).

The wood powder derives from the cutting and sanding processes applied to the piece of wood; it must be smaller than $0.5 \mathrm{~mm}$. The sawdust is a waste measuring between $0.5 \mathrm{~mm}$ and $2.5 \mathrm{~mm}$ that derives from the cutting and machining processes applied to pieces of wood. The wood shaving measures more than $2.5 \mathrm{~mm}$ and derives from machining, drilling and grinding (cleaning of the workpiece faces) processes. The woodchip measures at most $50 \times 20$ mm (CASAGRANDE JUNIOR et al., 2004; PIEKARSKI et al., 2017).

Bio-oil

Bio-oil is an organic, renewable fuel obtained through biomass thermal conversion. It has been gaining great prominence since it is a highly-oxygenated liquid material ease to be transported, stored and converted into materials of high added-value (MOHAN et. al, 2006; COLARES, 2011; TORRI, 2013; KAN et al., 2016). The bio-oil is a dark-brown microemulsion composed of highly-oxygenated hydrocarbons and water. Its elemental composition is very close to that of biomass and is formed by the rapid and simultaneous depolymerization and fragmentation of its main components 
(cellulose, lignin and hemicellulose) through thermal processes (MOHAN et. al, 2006; CZERNIK; BRIDGWATER, 2004; BRIDGWATER, 2012; TORRI, 2013; MOTA, 2014; PATEL and KUMAR, 2016; DHANAVATH et al., 2017).

According to Torri (2013), the quality of the bio-oil is influenced by process conditions and biomass type. Thus, it is necessary conducting a complete and detailed bio-oil characterization in order to assess its real potentialities. Many compounds such as phenols, ketones, carboxylic acids, hydrocarbons, sugars, among others, are formed during depolymerization and fragmentation processes (TORRI, 2013; ZHANG et al., 2013). Thus, this composition allows bio-oils to present great potential for many applications; however, their application is a great challenge due to their peculiar physicochemical properties (BRIDGWATER, 2012). Therefore, among the possibilities of use, the fossil fuel replacement by bio-oil has been the main motivation for studies in this field.

\section{Carbon black}

Carbon black is practically the impure carbon element that, in the form of quasi-spherical particles, is produced by the incomplete combustion or thermal decomposition of liquid or gaseous hydrocarbons. It presents black color and is often a very fine powder. Carbon black is one of the 50 most manufactured chemicals in the world; $90 \%$ of all carbon black is used in rubber applications, $9 \%$ of it is used as pigment, and the remaining 1\% is used as ingredient in hundreds of different applications (RODA, 2011; ZHANG et al., 2013; KAN et al., 2016). According to the company Global Material Supply Management (GMSM, 2016), the combination between particle size and aggregate shape or particle structure gives peculiar features to each carbon black type, which are known for its international nomenclature, namely: N-115, N-339, N-550, N-762, among others.

\section{Methodology}

Characterizing the crude MDF

Thermal analyses applied to the crude MDF were initially performed through Differential Scanning Calorimetry (DSC) in order to set the calorific value of the sample before they underwent the herein proposed treatments. The DSC curves were generated in a heat-flow type differential scanning calorimetric module DSC 910 (TA Instruments) coupled to a TA2000 thermal analyzer (TA Instruments).

In addition to the calorific value setting, a multi-elemental analysis was performed to characterize toxic elements such as $\mathrm{Al}, \mathrm{Ba}, \mathrm{Cd}, \mathrm{Cr}, \mathrm{Cu}, \mathrm{Ni}$ and $\mathrm{Pb}$, which could be found at the time to prepare the bio-oil and the carbon black or which could sprinkle during the burning process. An inductively coupled plasma optical emission spectrometer (ICP-OES - Optima DV 4300 model, Perkin Elmer) was used to observe the plasma in the axial and radial configuration modes in order to assure a more sensitive observation of each element. The ICP-OES analysis conditions are described in Table 1. The herein adopted optimizations were conducted according to Gomes et al. (2016). For digestion of those samples were used procedures opening samples of environmental origin by acid digestion as proposed by Bianchi and coworkers (2012) and Salazar et al (2011). 
Table 1 - ICP-OES instrumental parameters for the quantitative analysis of toxic metals in MDF samples

\begin{tabular}{|c|c|}
\hline Analysis parameter & Value \\
\hline Argon flow & $10 \mathrm{~L} / \mathrm{min}$ \\
\hline Nebulizer flow & $0.54 \mathrm{~L} / \mathrm{min}$ \\
\hline Auxiliary gas flow & $0.2 \mathrm{~L} / \mathrm{min}$ \\
\hline Reading reference & $15 \mathrm{~mm}$ \\
\hline Radio frequency power & $1450 \mathrm{~W}$ \\
\hline Peristaltic pump flow & $1.50 \mathrm{~mL} / \mathrm{min}$ \\
\hline Curve equation & Forced Zero Curve / Area Integration Calculation \\
\hline Nebulizer type & Cross Flow coupled to a Scott Spray Chamber \\
\hline Torch position & -3 \\
\hline Wavelength (nm) & $\begin{array}{c}\mathrm{Al}(396.153), \mathrm{Ba}(455.503), \mathrm{Cd}(228.802), \mathrm{Cr}(267.716), \\
\mathrm{Cu}(327.398), \mathrm{Ni}(231.604), \mathrm{Pb}(220.356)\end{array}$ \\
\hline
\end{tabular}

Immediate analysis

The immediate MDF shaving composition (fresh sample) was assessed through the content (in mass percentage) of some components found in the MDF structure, according to specific standards, namely: E871-82 (ASTM, 2006), E1755-01 (ASTM, 2007) and E987-82 (ASTM, 2006).

Determining the moisture content

An adaptation of the E871-82 standard (ASTM, 2006) was used to determine the moisture content.

Firstly, three Petri dishes were dried in a DeLeo oven for $30 \mathrm{~min}$ (Figure 1a), heated at $103 \pm 1^{\circ} \mathrm{C}$, and placed in a desiccator for approximately 1 hour, until reaching room temperature. Next, their masses were weighed in a scale (Bel Equipamentos), as shown in Figure 1b. The masses were recorded as $\mathrm{m}_{\mathrm{c}}$.

One (1) g of biomass sample was added to each Petri dish of the triplicate. Thus, the dish mass added with the biomass was recorded as $\mathrm{m}_{0}$. After this procedure was concluded, the dishes containing the samples were placed in an oven at $103 \pm 1^{\circ} \mathrm{C}$, for 16 hours. Next, the samples were left to cool in a desiccator at room temperature for 1 hour. Subsequently, the resulting mass was weighed and recorded as $\mathrm{m}_{\mathrm{f}}$. The samples returned to the oven for another hour. Then, they were removed from the oven, placed in a desiccator and weighed 1 hour later (this procedure was repeated until the mass change was lower than $0.2 \%$ ). The moisture content was determined through (1), in \%:

$\mathrm{MC}=\left[\left(\mathrm{m}_{0}-\mathrm{m}_{\mathrm{f}}\right) /\left(\mathrm{m}_{0}-\mathrm{m}_{\mathrm{c}}\right)\right] \cdot 100$ 
Wherein:

$\mathrm{m}_{\mathrm{c}}=$ Petri dish mass $(\mathrm{g})$,

$\mathrm{m}_{\mathrm{f}}=$ Final mass of the Petri dish containing the sample $(\mathrm{g})$, and

$\mathrm{m}_{0}=$ Initial mass of the Petri dish containing the sample $(\mathrm{g})$.

Determining the ash content

An adaptation of the E1755-01 standard (ASTM, 2007) was used to determine the ash content.

Porcelain crucibles $(50 \mathrm{~mL})$ were heated in a muffle furnace (Figure 1c) at $500^{\circ} \mathrm{C}$ for approximately 3 hours. Next, they were cooled to room temperature in a desiccator and then weighed; their masses were recorded as $\mathrm{m}_{\text {cont }}$. Each crucible of the duplicate was added with $1 \mathrm{~g}$ of MDF shavings. The crucibles containing the biomass samples were weighed and their masses were recorded as $\mathrm{m}_{\mathrm{bc}}$. Subsequently, the crucibles were placed in a muffle at $500^{\circ} \mathrm{C}$, under $5^{\circ} \mathrm{C} / \mathrm{min}$ speed (for the ramp and threshold program). Subsequently, they were cooled in a desiccator for 1 hour and weighed; their masses were recorded as $\mathrm{m}_{\text {ashes }}$. The ash content (AsC) was determined according to (2), in\%:

$\mathrm{AsC}=\left[\left(\mathrm{m}_{\text {ashes }}-\mathrm{m}_{\text {cont }}\right) /\left(\mathrm{m}_{\mathrm{bc}}-\mathrm{m}_{\mathrm{cont}}\right)\right] \cdot 100$

Wherein:

$\mathrm{m}_{\text {ashes }}=$ ash mass in the sample $(\mathrm{g})$,

$\mathrm{m}_{\text {cont }}=$ dry crucible mass $(\mathrm{g})$, and

$\mathrm{m}_{\mathrm{bc}}=$ mass of the crucible containing the biomass $(\mathrm{g})$.

\subsubsection{Determining the content of volatile materials}

This procedure was conducted according to an adaptation of the E872-82 standard (ASTM, 2006).

Two 50-mL porcelain crucibles (with lid) were herein used to simulate an inert atmosphere. They were weighed and their respective masses were registered as $\mathrm{m}_{\mathrm{c}}$. Next, they were added with $1 \mathrm{~g}$ of biomass and the masses of the crucibles (with lid) containing the sample were recorded as $\mathrm{m}_{0}$. Subsequently, the crucibles were placed in a muffle with N1 100 controller (Figure 1c), at $500^{\circ} \mathrm{C}$, under $5^{\circ} \mathrm{C} / \mathrm{min}$ speed (ramp temperature for ramps and thresholds' programming). The containers were weighed after being cooled to room temperature for 1 hour in a desiccator, and the final mass was recorded as $\mathrm{m}_{\mathrm{f}}$. The volatile material content (VMC) was calculated in \%, according to (3):

$\mathrm{VMC}=\left[\left(\mathrm{m}_{0}-\mathrm{m}_{\mathrm{f}}\right) /\left(\mathrm{m}_{0}-\mathrm{m}_{\mathrm{c}}\right)\right] \cdot 100$

Wherein:

$\mathrm{m}_{\mathrm{c}}=$ mass of the porcelain crucible (with lid) $(\mathrm{g})$,

$\mathrm{m}_{\mathrm{f}}=$ final mass of the porcelain crucible (with lid) containing the sample $(\mathrm{g})$, and

$\mathrm{m}_{0}=$ initial mass of the porcelain crucible (with lid) containing the sample (g). 


\subsubsection{Determining the fixed carbon}

The difference between the total sample (100\%), on a dry basis, and the ash and volatile material contents was calculated in order to find the fixed carbon content in \%, using (4):

$\mathrm{CC}=100-\mathrm{AsC}-\mathrm{VMC}$

wherein:

$\mathrm{CC}=$ fixed carbon content $(\%)$,

$\mathrm{AsC}=$ ash content $(\%)$, and

$\mathrm{VMC}=$ volatile material content $(\%)$.

Full Factorial Planning and Pretreatment

The aim of the current stage was to assess the carbon black or bio-oil obtainment conditions according to different temperature profiles, digestion times and acid types. The Doehlert planning was used to optimize these conditions. According to Table 2, it was necessary conducting $27\left(3^{3}\right)$ different experiments using all possible factor level combinations; this planning is called full factorial $\left(3^{3}\right)$. The effects of three concentrated acid types such as nitric acid - $\mathrm{HNO}_{3}(-1)$, sulfuric acid $-\mathrm{H}_{2} \mathrm{SO}_{4}$, and hydrochloric acid - $\mathrm{HCl}(+1)$ were analyzed at three different temperatures $-25^{\circ} \mathrm{C}(-1), 75^{\circ} \mathrm{C}(0)$ and $150^{\circ} \mathrm{C}(0)$-, in three digestion times $-30 \mathrm{~min}(-1), 60 \mathrm{~min}(0)$ and $90 \mathrm{~min}(+1)$.

Table 2 - Planning matrix

\begin{tabular}{l|c|c|c}
\hline Factors & $(-1)$ & $(0)$ & $(+1)$ \\
\hline (A) Temperature & $25^{\circ} \mathrm{C}$ & $75^{\circ} \mathrm{C}$ & $150{ }^{\circ} \mathrm{C}$ \\
\hline (B) Acid type & Nitric & Sulfuric & Hydrochloric \\
\hline (C) Digestion time & $30 \mathrm{~min}$ & $60 \mathrm{~min}$ & $90 \mathrm{~min}$ \\
\hline
\end{tabular}

An acid digestion procedure was performed to pretreat the MDF sample; $1 \mathrm{~g}$ of MDF shavings was weighed in a beaker and transferred to a 14-mm test tube.

Four (4) $\mathrm{mL}$ of concentrated acid was pipetted in a hood and added to the tube containing the sample. The tube was closed and stirred in circular motion; it was held by the lid and opened from time to time in order to release the pressure until the mixture became visually homogeneous. The tube heating was carefully performed in order to avoid sample projection and possible contamination.

Then, the tubes were placed in the digestion block, also inside the hood. The acid digestion was carried out in a PoliControl Thermo Digest COD digestion block with digital temperature and time control. The digestions were done according to previous planning (Table 2). At the end of the digestion process, the tubes were removed from the block and left to cool.

Finally, the resulting material was transferred to the $15-\mathrm{mL}$ falcon tubes, which were labeled according to the number of the experimental condition in order to assure traceability; the central condition was done in triplicate. It is worth highlighting that the sample pretreatment stage is the most rigorous among all the analytical operations, since more mistakes are made and more time and money are spent at this stage. Thus, all the herein used acids, solid reagents 
and solutions were of analytical grade. The water used in the multi-elemental featuring was deionized through a Milli-Q system.

\section{Results and discussion}

Table 3 shows the multi-elemental featuring of three MDF samples conducted through ICP-OES. It is possible seeing the strong presence of aluminum and barium in the MDF samples. These contents may have interfered in the DSC analyses, since the MDF did not fully burn. In addition, the MDF samples used in these experiments were very heterogeneous. The results of the other elements were lower than the detection limit (DL), which is the lowest measurable mass or concentration.

Metals can be found almost everywhere in the environment; however, some of them are essential for the ecosystems in general. Nevertheless, these metals associated with airborne particles contribute to the contamination of aquatic and terrestrial ecosystems, depending on their amount in the environment.

Table 3 - Results (mg/kg) of $\mathrm{Al}, \mathrm{Ba}, \mathrm{Cd}, \mathrm{Cr}, \mathrm{Cu}, \mathrm{Ni}$ and $\mathrm{Pb}$ in MDF samples analyzed through ICP-OES.

\begin{tabular}{c|c|c|c|c|c|c|c}
\hline $\mathrm{mg} / \mathrm{kg}$ & $\mathrm{Al}$ & $\mathrm{Ba}$ & $\mathrm{Cd}$ & $\mathrm{Cr}$ & $\mathrm{Cu}$ & $\mathrm{Ni}$ & $\mathrm{Pb}$ \\
\cline { 1 - 3 } MDF 1 & $326.82 \pm 2.54$ & $22.39 \pm 0.77$ & & & & & \\
\cline { 1 - 3 } MDF 2 & $256.11 \pm 6.31$ & $6.88 \pm 0.01$ & $<0.005$ & $<0.029$ & $<0.008$ & $<0.02$ & $<0.009$ \\
\hline MDF 3 & $743.93 \pm 14.04$ & $24.55 \pm 0.78$ & & & & & \\
\hline
\end{tabular}

The thermograms obtained through DSC (Figures $1 \mathrm{a}, \mathrm{b}, \mathrm{c}$ ), which used crude MDF as sample, showed that the DSC curves presented peaks, mostly exothermic (upward), due to oxidation and decomposition, fact that confirmed that the MDF sample was an energy-supply source.

The other processes resulting from deviations from the baseline correspond to chemical processes, as shown in the graphs. Processes such as dehydration (from 0 to $250^{\circ} \mathrm{C}$ ), reductions and certain decomposition reactions from $250^{\circ} \mathrm{C}$ on, have produced endothermic peaks. Fixed solid contents, which are the inorganic matters formed by salts in the elements derived from the samples, were found at temperatures above $900^{\circ} \mathrm{C}$.

Table 4 shows the results of the immediate analysis conducted in the biomass samples. It was possible seeing approximately $7 \%$ moisture content (MC) in the samples; therefore, the heat production per mass unit was higher. The ash content (AsC) not exceeding 18.5\% originated from elements already present in the MDF sample. The volatile material content (VMC) presented relatively high value $(>65 \%)$, and it showed that the biomass burned easily. Finally, it was also possible seeing that the biomass was not carbon-rich (CC), since it did not exceed $16.5 \%$ of the composition of all materials. It happened because of the time the sample was stored for, which made it lose its natural properties. 


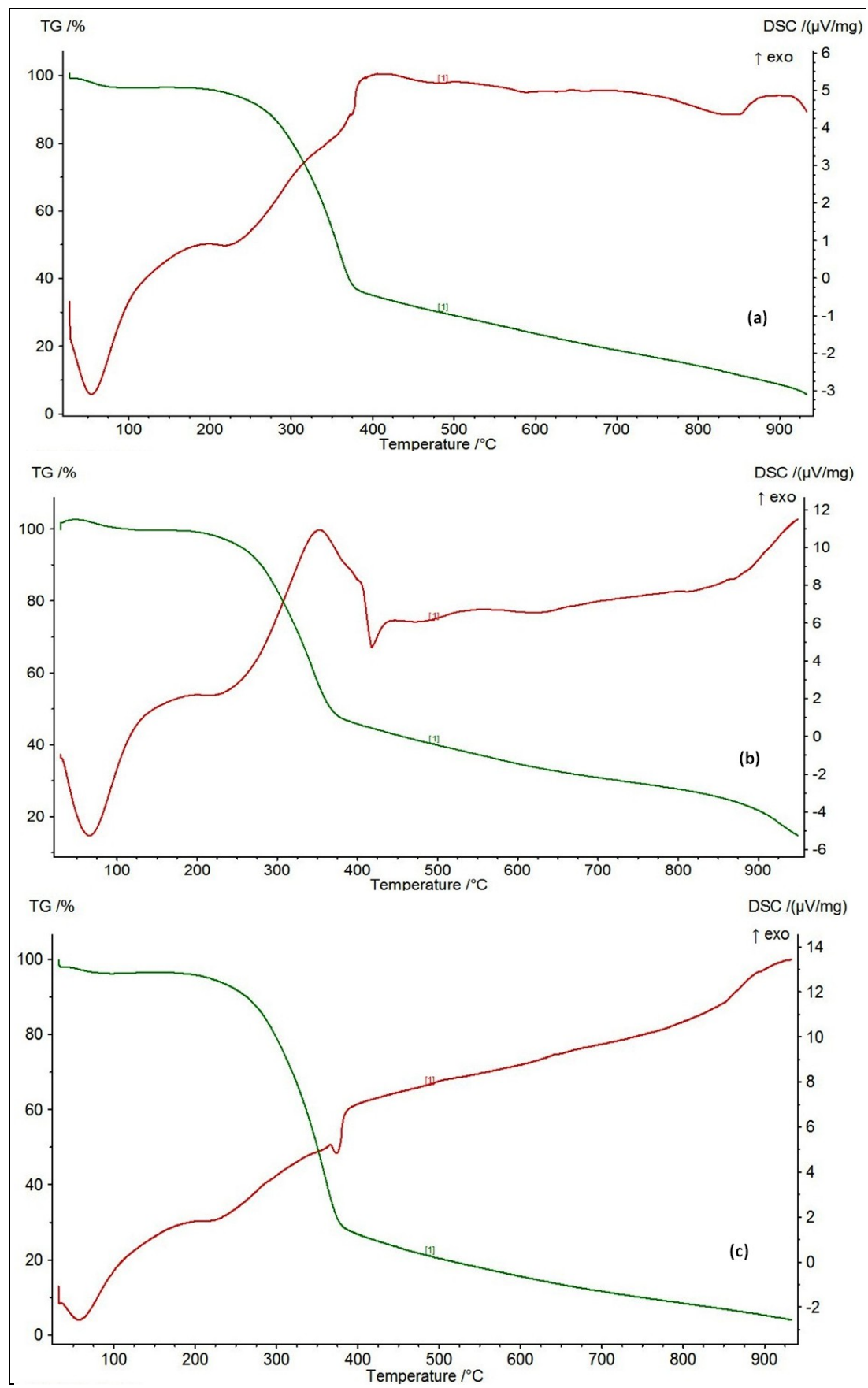

Figure 1 - a) First crude MDF thermogram 1; b) Second crude MDF thermogram; c) Third crude MDF thermogram

Table 4 - Results (\%) of the immediate analysis conducted in the fresh sample

\begin{tabular}{cccc}
\hline $\mathrm{MC}(\%)$ & $\mathrm{AsC}(\%)$ & $\mathrm{VMC}(\%)$ & $\mathrm{CC}(\%)$ \\
\hline $7.18 \pm 0.08$ & $18.44 \pm 2.89$ & $65.10 \pm 2.13$ & 16.46 \\
\hline
\end{tabular}


The sample heating (whether it was performed in the digestion block or not) during the digestion process led to its decomposition, which was followed by color change or by the formation of acid gases or vapors. Figures 2 and 3 depict the results of the 27 wet-digestion experiments conducted in the current study.

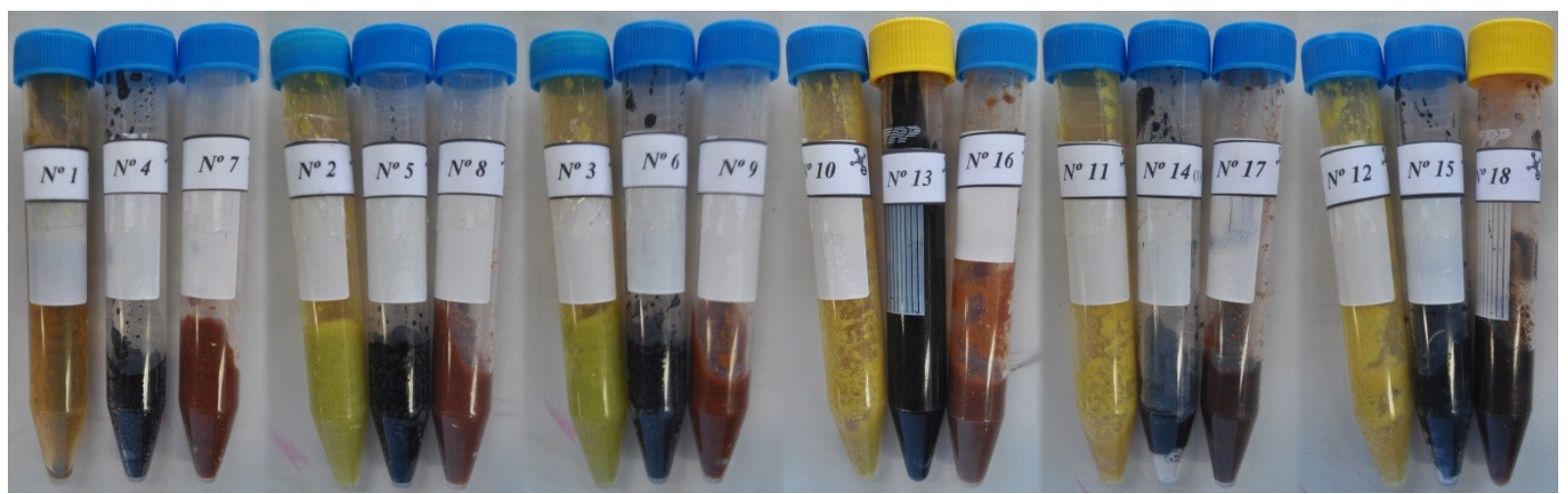

Figure 2 - Results from 1 to 9 (acid digestion at $25^{\circ} \mathrm{C}$ ), and results from 10 to 18 (acid digestion at $75^{\circ} \mathrm{C}$ ) concerning the samples subjected to nitric, sulfuric and hydrochloric acids, respectively, in the three herein defined digestion times.

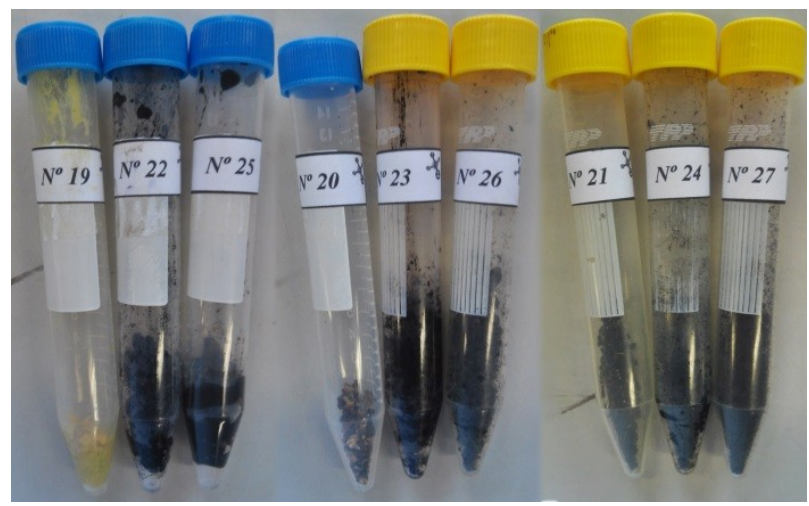

Figure 3 - Results from 19 to 27 (acid digestion at $150^{\circ} \mathrm{C}$ ) of the samples subjected to nitric, sulfuric and hydrochloric acids, respectively, in the three herein defined digestion times

The best condition for bio-oil formation was at temperature 25 to $75^{\circ} \mathrm{C}$ using sulfuric acid, because of the appearance and formation of carbon black and/or furfural under the other conditions. However, the digestion conducted at $25^{\circ} \mathrm{C}$ did not lead to full biomass decomposition; therefore, the ideal condition for bio-oil formation was at temperature $75^{\circ} \mathrm{C}$ in sulfuric acid medium.

The experiments 20 and 21 (digestions in nitric acid medium, from $60 \mathrm{~min}$ on) and the experiments 26 and 27 (digestion in hydrochloric acid medium, from $60 \mathrm{~min}$ on) led to carbon black formation. It was possible seeing furfural formation in the digestion conducted in hydrochloric acid medium.

The carbon black, in turn, is one of the most common particulate material types. It is a disadvantage because carbon black forms the so-called aerosols when it is dispersed in the air. Thus, this particulate material directly affects 
the environment, as well as the species living in it. The main carbon black disadvantage, according to the current study, lies on the fact that it negatively affects thermal stability, which is a property showing resistance to temperature changes.

The biomass-generated furfural shows low yield and cannot be used for high-end purposes. In energy terms, the furfural can inhibit biomass ethanol formation, i.e., it is not possible simultaneously producing ethanol and another fuel from a single sample.

\section{Conclusions}

In light of the foregoing, it is possible concluding that the acid digestion process is a good biomass converter in the production of bio-oil, energy and high added-value chemical products. It is also possible concluding that the differential scanning calorimetry (DSC) generates curves presenting endothermic or exothermic peaks, thus characterizing the physical and chemical phenomena. Some information could be obtained from the curves and from data generated from them: the MDF-shaving biomass is a strong candidate to be used in the production of energy derivatives. However, it is necessary conducting a multi-elemental analysis to better understand the chemical elements in the sample structure, since they can interfere in the immediate analysis, as well as in the amount of generated heat, besides their possible toxicity when they get in contact with the air. In addition to the analyses, it is worth investigating the fresh sample's features (moisture, ash, volatile material and fixed carbon contents) through the conversion technology. The properties of the herein studied biomass are suitable for energy generation, since they showed low humidity, low ash content, and high volatile material content; however, they showed low fixed carbon content. It is essential replacing non-renewable industrial raw materials by renewable raw materials able to cause less environmental impact in order to allow contemporary society to become sustainable in the mid- and long-terms. The results enabled concluding that the bio-oil generated in the current study can be used as an alternative energy source to replace fossil sources. In addition, the carbon black formed in some experiments can be used as fertilizer and/or pigment, and as reinforcer in automobile tires. Furthermore, the furfural formed in the other experiments can be used as solvent or as starting material to prepare other organic solvents.

\section{Acknowledgement}

The authors are grateful to Fundação de Amparo à Pesquisa do Estado do Rio Grande do Sul (FAPERGS, Process N.: 0465-2551/15-0) for research funds and grants.

\section{Referências}

ABREU, LB, MENDES, LM, SILVA, JRM, PAULA, LER, MORI, FA. Avaliação de resíduos de painéis de madeira gerados por indústrias moveleiras para aproveitamento na confecção de pequenos objetos - estudo de caso. Ciênc. Agrotec., 2009;33:1747-1751. Available from: http://www.scielo.br/scielo.php?script=sci_arttext\&pid=S141370542009000700008 
AMERICAN SOCIETY FOR TESTING AND MATERIALS (ASTM). Standard E1755 - 01, Standard Test Method for Ash in Biomass. 2007.

AMERICAN SOCIETY FOR TESTING AND MATERIALS (ASTM). Standard E871 - 82, Standard Test Method for Moisture Analysis of Particulate Wood Fuels. 2006.

AMERICAN SOCIETY FOR TESTING AND MATERIALS (ASTM). Standard E872 - 82, Standard Test Method for Volatile Matter in the Analysis of Particulate Wood Fuels. 2006.

BRIDGWATER, AV. Review of fast pyrolysis of biomass and product upgrading. Biomassa and Bioenergy, 2012;(38):68-94. Available from: http://www.sciencedirect.com/science/article/pii/S0961953411000638

BERWANGER, CC, VASCONCELLOS, NJS, PEIXOTO, SC, SWAROWSKY, A, SALAZAR, RFS. Quality control of B100 biodiesel obtained from soy biodiesel processing-Technical note. Ciência e Natura, 2015;37(3):740-746.

BIANCHI, SR, AMAIS, RS, PEREIRA, CD, SALAZAR, RFS, NOBREGA, JA, NOGUEIRA, ARA. Evaluation of a collision-reaction interface (CRI) for carbon effect correction on chromium determination in environmental samples by ICP-MS. Analytical Letters, 2012;45(18):2845-2855.

CASAGRANDE JUNIOR, EF, SILVA, MC, CASSILHA, AC, PODLASEK, CL, MENGATTO, SNF. Industria moveleira e resíduos sólidos: considerações para o equilíbrio ambiental. Revista Educação e Tecnologia, 2004;(8):1-22. Available from: http://revistas.utfpr.edu.br/pb/index.php/revedutec-ct/article/view/1142

COLARES, DG. Florestas energéticas e resíduos são fontes de bio-óleo e bio-carvão. 2011. [cited 2017 apr 11] Available from: http://www.infobibos.com/Artigos/2011_2/BioOleo/index.htm

CORTEZ, LAB, LORA, EES, GÓMEZ, EO. (Org.). Biomassa para energia. Campinas: Editora da Unicamp; 2008.

CZERNIK, S, BRIDGWATER, AV. Overview of Applications of Biomass Fast Pyrolysis Oil. Energy Fuels, 2004;18(2):590-598. Available from: http://pubs.acs.org/doi/abs/10.1021/ef034067u

DHANAVATH, KN, SHAH, K, BANKUPALLI, S, BHARGAVA, SK, PARTHASARATHY, R. Derivation of optimum operating conditions for the slow pyrolysis of Mahua press seed cake in a fixed bed batch reactor for bio-oil production. Journal of Environmental Chemical Engineering. 2017;5(4):4051-4063.

FERREIRA, SD. Estudo da viabilidade da conversão térmica de resíduos de fibra de média densidade (MDF) [Dissertation]. Caxias do Sul: Programa de Pós-Graduação em Engenharia Mecânica/UCS; 2013.110 p.

GLOBAL MATERIAL SUPPLY MANAGEMENT (GMSM). Negros de fumo para borracha. 2016. [cited 2016 set 04]. Available from: http://www.gmsm.com.br/negrosdefumo

GOMES, BCV, KUMMER, G., PEREIRA, M. M. S. M., IZÁRIO FILHO, H. J., SALAZAR, R.F.S., VASCONCELLOS, N. J. S. Potencial toxicológico de metais presentes em solos de cemitérios de Santa Maria - RS. Revista Ambiente \& Água, 2016;11(1):145-155.

HUBER, GW, IBORRA, S, CORMA, A. Synthesis of transportation fuels from biomass: chemistry, catalysts, and engineering. Chemical Reviews, 2006;106(9):4044-4098.

JUVENAL, TL, MATTOS, RL. Painéis de Madeira Reconstituída. Banco Nacional do Desenvolvimento (BNDES). Área de Setores Produtivos $1-$ SP1, jun. 2002. [cited 2016 mar 8]. Available from: http://www.bndes.gov.br/SiteBNDES/export/sites/default/bndes_pt/Galerias/Arquivos/conhecimento/relato/relato02.pdf

KAN, T, STREZOV, V, EVANS, TJ. Lignocellulosic biomass pyrolysis: A review of product properties and effects of pyrolysis parameters. Renewable and Sustainable Energy Reviews. 2016;(57):1126-1140.

KLASS, DL. Biomass for Renewable Energy, Fuels, and Chemicals. Barrington: Academic Press;1998.

KOUCHAKI-PENCHAH, H, SHARIFI, M, MOUSAZADEH, H, ZAREA-HOSSEINABADI, H. Life cycle assessment of medium-density fiberboard manufacturing process in Islamic Republic of Iran. Journal of Cleaner Production. 2016;(112):351-358.

MAFFESSONI, D, MENEGUZZI, A. Diagnóstico da gestão dos resíduos de madeira e de chapas nas indústrias do Pólo Moveleiro de Bento Gonçalves. In: Proceedings of 3rd Congresso Internacional de Tecnologias para o Meio Ambiente [CD-ROM]; 2012 abr 25-27; Bento Gonçalves, Brasil. p. 1-8.

MOHAN, D, PITTMAN, CU, STEELE, PH. Pyrolysis of wood/biomass for bio-oil: a critical review. Energy \& fuels. 2006;20(3):848-889. 
MOTA, D. Caracterização físico-química do material particulado emitido por forno de pizzaria: estudo de caso da Pizzaria Achiropizza. Ciência e Natura, 2014;36(2):258-267.

PATEL, M, KUMAR, A. Production of renewable diesel through the hydroprocessing of lignocellulosic biomassderived bio-oil: A review. Renewable and Sustainable Energy Reviews. 2016;(58):1293-1307.

PIEKARSKI, CM, FRANCISCO, AC, LUZ, LM, KOVALESKI, JL, SILVA, DAL. Life cycle assessment of mediumdensity fiberboard (MDF) manufacturing process in Brazil. Science of the Total Environment. 2017;(575):103-111.

RODA, DT. Negro de fumo. Tudo sobre Plásticos, 2011. [cited 2016 abr 10]. Available from: http://www.tudosobreplasticos.com/pigmentos/negrodefumo.asp

SALAZAR, RFS, ALCÂNTARA, MAKD, IZÁRIO FILHO, HJ. Evaluation of sample preparation methods and optimization of nickel determination in vegetable tissues. Revista Brasileira de Ciência do Solo, 2011;35(1):241-248.

TORRI, IDV. Caracterização de bio-óleos obtidos por pirólise da serragem de Eucalyptus sp. (hardwood) e Picea abies (softwood) utilizando as técnicas de cromatografia gasosa acoplada à espectrometria de massas [Thesis]. Porto Alegre: Instituto de Química/UFRGS; 2013. 139 p.

VAZ JUNIOR, S. Biorrefinarias: cenários e perspectivas. Embrapa Agroenergia. Brasília: Athalaia, 2011.

ZHANG, L, LIU, R, YIN, R, MEI, Y. Upgrading of bio-oil from biomass fast pyrolysis in China: A review. Renewable and Sustainable Energy Reviews. 2013;(24):66-72. 